\title{
News media representation on EU immigration before Brexit: the 'Euro-Ripper' case
}

Marta Martins ${ }^{1 凶}$

A higher level of mobility of people has marked the European Union (EU), with immigrants moving from one place to another, every year, looking for a better quality of life, often fleeing from war and poverty. In the wake of enlargement of the European Union, the United Kingdom (UK) experienced high inward migration. One of the main focuses of UK media coverage was immigration from Eastern European countries. The UK referendum on Brexit on 23 June 2016, was followed by an increase in hate crimes linked to migration issues and, subsequently, a media apparatus of toxic discourse and fear of the criminal 'Other'. This paper aims to reveal how newspaper articles and personal comments written in response to these articles, represented creative and media-driven anxieties about 'opening' borders in the EU. The empirical sample builds on news media coverage of the 'Euro-Ripper' case, published in two UK newspapers-the Daily Mail and The Independent. Based on critical surveillance studies and cultural media studies, I elaborate on the notion of moral panic, dramatised by the media, which mobilises specific compositions of 'otherness' by constructing suspicion and criminalising inequality by particular social and ethnic groups and nationalities. I argue that the media portrays the dramatisation of transnational narratives of risk and (in)security, which redraws territorial borders and (re)define Britain's global identity. The analysis shows how the news media in the Brexit vote continually raised and legitimised awareness related to the migration as a vehicle that enables the 'folk-devil' to cross borders. This context postulates an ideology that converges on a relationship of intransigence and criminal convictions, in the context of a politics of inclusion and exclusion. I conclude by emphasising how the media intersects different social and geographical spaces in which migration takes place. Media-constructed categories of suspicion targets have been previously created and 'suspect communities' have already been socially accepted, thereby confirming and reshaping understandings of their identities and communities.

\footnotetext{
${ }^{1}$ University of Minho, Institute for Social Sciences, Campus de Gualtar, 4710-057 Braga, Portugal. ${ }^{凶}$ email: martamartins340@gmail.com
} 


\section{Introduction}

broad level of mobility of people has marked the European Union (EU) with immigrants moving from one place to another, every year, looking for a better quality of life, driven primarily by economic factors, such as poverty and lack of employment, and also to escape from war. According to the 2020 report by the International Organization for Migration (IOM) in 2019 , it is estimated that there are 272 million immigrants in the world, equivalent to $3.5 \%$ of the global population (International Organization for Migration, 2020). According to the data, the majority of the population does not cross-national borders, and remains in its home country. The United Kingdom (UK) has had one of the highest levels of immigration, with the flow of immigrants increasing until 2016. With Britain as a member of the EU, EU migrants can relatively freely work and live in Britain under the right of free movement of people. However, contrary to media narratives, these inflows have significantly decreased since then (Clegg, 2019, p. 8). Yet, the discussion of how immigration influenced (or not) the Brexit vote remains very uncertain. However, as expected, journalists show a greater interest in describing acts of violence committed by people that move around, whose mobility tend to be perceived as a contemporary security problem (see Curtice, 2017; Tong and Zuo, 2019; Walter, 2019).

In the wake of enlargement of the EU, the UK experienced substantial high inward migration. One of the main focuses of UK media coverage was immigration from Eastern European countries. Since 2007, after Romania and Bulgaria joined the EU, the media focused on symbolic, social and political mobility between citizens "inside" and "outside" the EU, reinforcing a pre-existing demarcation between West and East. The enduring public perceptions of these high inward migration was recreated by a persuasive media rhetoric concerning the overall negative impact of "immigration on jobs, wages, housing or the crowding out of public services" (Wadsworth, 2015, p. 1). These developments in relation to anti-immigration feelings shaped the period during which the UK decided to leave the EU. The result of the UK's Brexit referendum, held on June 23, 2016, was followed by an increase in hate crimes linked to migration issues and, subsequently, a media apparatus of toxic discourse and fear of the criminal 'Other' (Goodwin and Milazzo, 2017; Curtice, 2017; Eberl et al., 2018). The case of the 'Euro-Ripper', which is how the criminal case has become known in the UK press, is one example of the biased media coverage linked to migrants. The case received significant media coverage because of the efficacy of transnational exchange of DNA data in the EU to identifying the first serial killer who crossed borders to commit various crimes, which constitutes another dimension of my research ${ }^{1}$.

On May 21, 2015, the 'Euro-Ripper', named Dariusz Pawel Kotwica, a 29-year-old Polish citizen, brutally murdered an elderly couple in Vienna, Austria. This case had transnational dimensions: the investigations went beyond the crimes committed in Austria. It was also alleged that he committed other crimes in several countries across the EU, including the UK (Beckford, 2015). Media coverage of the case was incorporated within the referendum debate. The case sparked so much online interest that it can be considered to be a relevant and robust case concerning 'porous borders' and the fluidity of movement across the EU. The press has gradually tended to focus on the idea that 'EU immigration' concerns a local community that is moving across EU borders, the "not yet European" (Kuus, 2004, p. 37). After 47 years, the UK has now left the EU. Until now, the British media has never ceased to stress the destructive impacts of the 'migratory crisis' (Griffiths, 2017; Fox, 2018; Hutching and Sullivan, 2019).
While several researchers have focused on traditional media portrayals of migrants and crime, in the context of assessments of Brexit (see Dorling, 2016; Gurminder 2017; Benson, 2019) there has been less research into its effects and practices that affect public attitudes (see Griffiths, 2017; Fox, 2018; Hutchings and Sullivan, 2019). This paper is interested in demonstrating how newspaper articles and personal comments written in response thereof, represented creative and media-driven anxieties about 'opening' borders in the EU. Precisely, I analyse how online audiences can reflect the "perspectives of a large segment of the population" (Henrich and Holmes, 2013, p. 2) and therefore are the most suitable way for citizens to express their authentic opinion on a specific topic that is also discussed by other readers (see Da Silva, 2013; Coe et al., 2014). The study was inspired by the potential for critical discussion and a unique opportunity to provide a relevant case study about the context of the Brexit debate and EU immigration dialogue.

The empirical sample builds on a news media related to coverage of the 'Euro-Ripper' case. Based on critical surveillance studies and cultural media studies, I elaborate on the notion of moral panic (Cohen, 2002; Goode and Ben-Yehuda, 1994) dramatised by the media, which mobilises specific compositions of otherness by constructing suspicion and criminalising inequality by particular social and ethnic groups and nationalities. I analyse 'moral panic' as distortion and amplification of "significant others" (Dumitrescu, 2018, p. 82) caused and legitimised by the media. The distorted image materialises the myth of "folk-devils" characterised as "agents responsible for the threat" (Goode and Ben-Yehuda, 1994, p. 149). Once the figure of the "devil" has been formulated, through the creation of a moral panic, it is easily recognisable. In other words, "folk devils are deviants; they are engaged in wrongdoing; their actions are harmful to society; they are selfish and evil; they must be stopped, their actions neutralised" (Goode and Ben-Yehuda, 1994, p. 29). These forms of anxiety generated by 'moral panic' represented by the media about who we should or should not fear (Krulichová, 2019). Thereby, media-constructed categories of previously created targets of suspicion and already socially accepted 'suspect communities', confirm and reshape understandings of their identities and communities (Pantazis and Pemberton, 2009; El-Enany, 2018; Abbas, 2019).

The article is structured as follows: section "The context of the 'Euro-Ripper' case" outlines the 'Euro-Ripper' case in the media context, focusing on the online debate related to the interlocking reactions of EU immigration after Brexit. Section "Data and methods" explains the methods that guided the design of the study. Drawing on the work of Goode and Ben-Yehuda (1994, p. 156) the analysis is conducted using "five crucial elements or criteria" of moral panic: Concern; Hostility; Consensus; Disproportionality and Volatility. The definition of moral panic stated by the five criteria it is the "most systematic historical and theoretical account of moral panic" (Ungar, 2001, p. 275). My analysis, therefore, outlines that the public reactions to the EU immigration rhetoric can be analysed within the framework of Stan Cohen's conceptualisation model, confirming the contemporary utility of moral panic analysis. I argue that the media portrays the dramatisation of transnational narratives of risk and (in)security, which redraws territorial borders and (re)defines Britain's global identity. The analysis shows how the news media in the Brexit vote continually raised and legitimised awareness related to migration itself as a vehicle that enables the 'folk-devil' to cross borders. This context postulates an ideology that converges on a relationship of intransigence and criminal convictions in a politics of inclusion and exclusion. I conclude by emphasising 
how the media intersects different social and geographical spaces in which migration takes place.

\section{The context of the 'Euro-Ripper' case}

On May 21, 2015, the newspapers described the violent circumstances in which an elderly couple of 75 and 74 years had been raped, tortured, mutilated and murdered in Vienna, Austria. Following transnational exchange of DNA data in the EU, a 29year-old Polish man, named Dariusz Pawel Kotwica, was identified (see Machado and Granja, 2018). Kotwica, or the 'EuroRipper', not only confessed to the crime, he also mentioned that several months earlier he had committed another murder in Sweden, near Gothenburg on April 23, of a 79-year old man. Additionally, he confessed that he robbed several stores in 2012 and committed another murder in Salzburg, Austria. Moreover, he admitted to causing grievous bodily harm in the Netherlands, in 2011. In 2015 he stole from a shop in Germany and committed a murder in Sweden. According to police reports, there is still the possibility of further possible murders in the Czech Republic and the Netherlands. Austrian police also found that Dariusz Pawel Kotwica remained in the UK for several years, and therefore suspicions were raised about the possibility that he may have committed other "serious crimes" there (Beckford, 2015; Khan, 2015). On June 8, 2015, the suspect was arrested at the Düsseldorf railway station in Germany and was immediately extradited to Austria, where he was tried.

The 'Euro-Ripper' immediately attracted major media attention. In particular, attention focused on his fluidity and flexibility of movement across six countries over several years. It is also suspected that he may have committed many crimes in the UK, where he lived for many years. Notably, his use of the EU's open borders became the focus of extreme and harrowing media narratives at the time of the Brexit referendum. This discourse became more pronounced in the UK news media, which focused its attention on 'Other migrants' who are crossing borders to find new victims. The agenda-setting raised several public voices who argued that a European society which facilitates freedom of movement of people, goods and services, offers a major opportunity for criminality (Bigo, 2002, 2014; El-Enany, 2018; Abbas, 2019; Benson, 2019).

My focus in this paper is to show how newspapers articles related to the 'Euro-Ripper' case, and personal text comments written in response to the articles, represented processes of belonging, (re)producing pre-existing inequalities and vulnerabilities about a sense of national community that incorporates British identity. A crucial element of this approach is that the online bubble has significantly changed the way that people react to each story and how their beliefs are formulated, "creating new spaces for political expression and participation" (Da Silva, 2013, p. 176). The following section describes the data and methods analysed in function of the selected newspapers.

\section{Data and methods}

For this study, I analysed the comments posted online in response to the two articles published in two UK newspapers related to the 'Euro-Ripper' case. The first article was circulated in the Daily Mail (Beckford, 2015) entitled "Europe's first serial killer who raped and murdered his way across continent to Britain: Police investigate Pole who daubed bizarre phrases on woman's naked body in sickening crime spree across six countries" on 28 November 2015. And the article "Dariusz Pawel Kotwica: 'Europe's first serial killer' could have committed 'serious crimes' in Britain" published in The Independent (Khan, 2015) on 29 November 2015, after Dariusz Pawel Kotwica was arrested. These articles were selected due to extend and a variety of comments that it generated online. These offer a unique position to think about what inspired the commenters to write about the case.

As Ofcom released its annual report (2019) on news consumption in the UK, news users are more likely to access news through comments, news links and trends. Though these feature readers could create a conversation that strongly public deliberation of the online public sphere (see Dahlgren, 2009, p. 168). As Henrich and Holmes (2013, p. 2) explain, "comments cannot be taken as representative of the views of the general population. However, due to the high number of comments available on certain articles, they can reflect the perspectives of a large segment of the population". I refined the analyses in order to focus on the articles that received the most significant comments. Therefore, due to its news value, the data collection took place exclusively online and provided the presence of 250 comments in the Daily Mail and 14 comments in The Independent. I believe that the approach was sufficient and that the news environment provides a satisfactory proxy that significantly impacts public understanding. Similar to other studies (see Da Silva, 2013, 2015; Boyd, 2016), the selection was not made based on the newspapers with the largest circulation. An inclusion criterion was to embrace all comments directly related to the article.

The articles were posted under different platforms available for comments. Daily Mail is a daily newspaper, that is well-known amongst British citizens as a popular right-wing tabloid. In the broadsheet, The Independent, also a daily newspaper, tilted to the left of the political spectrum. Briefly, the tabloid press presents itself as a vehicle for news related to emotion, personal entertainment, with less relevance to politics, the economy, and society at large. The broadsheet press, predominantly, has the privilege of dealing with political, social, economic, and cultural themes with great celebrity to reflection and argumentation (Skovsgaard, 2014). At the European level and, according to Mihelj et al. (2008), both newspapers are general similarities and can be compared across countries.

The Daily Mail newspaper does not have a paywall, which therefore makes it easier for users to read and respond to articles. However, Daily Mail warns that all opinions expressed by users do not necessarily reflect the perspectives and views of the newspaper. It therefore adopts a pre-moderation strategy (see $\mathrm{Da}$ Silva, 2013, p. 182). The administration of comments, prior to their publication, implies that journalists carefully evaluate the quality of all comments before they are published. In The Independent, the comments appear in a section to share thoughts, which is stated to be freely accessible. This uses a postmoderation strategy, in which there is careful evaluation of comments. As a result, abusive comments, even after they have been notified by other users as inappropriate, can remain online for an extended period of time, and, this dynamic may even disrupt the path of the discussion (Da Silva, 2013, p. 183). In this specific circumstance, due to the undesirable course that many comments triggered, the newspaper progressively chose to delete some comments that did not obey with the established rules. Additionally, as a general rule, this type of interaction is a common way to provide "a truer insight into people's opinion than those expressed in other contexts" (Henrich and Holmes, 2013, p. 2 ), the vast majority of comments in both newspapers required registration, but the option to use a nickname made it possible to remain anonymous.

The analysis uses a grounded theory approach, with a "continuous interplay between analysis and data collection" (Strauss and Corbin, 1994, p. 273). The unit analysis chosen for coding was the paragraph, coded on the themes addressed following the principles of content analysis in qualitative research, using an approach which combines manifest and latent analysis contexts. For this article, the analysis has directed a careful and critical look 
at the social and symbolic representations that the press assumes on procedures used in the coverage of the criminal case, where the 'criminal other' are the epicentres of the crime narrative.

\section{Moral panic representations of EU immigration before Brexit} Since the original definition of 'moral panic' propounded by Cohen (1971, p. 9), the concept has served as an analytical tool. The concept has direct resonance with British press coverage of 'Euro-Ripper' case, in particular:

"A condition, episode, person or group of persons emerges to become defined as a threat to societal values and interests; its nature is presented in a stylised and stereotypical fashion by the mass media; the moral barricades are manned by editors, bishops, politicians and other right-thinking people; socially accredited experts pronounce their diagnosis and solutions; ways of coping are evolved or (..) resorted to; the condition then disappears, submerges or deteriorates and becomes more visible. (...)".

This concept, since its origin, has undergone a critical academic process. Other authors have followed its analytical conceptualisation. Besides the many advances derived from Cohen's work, I apply the approach proposed by Goode and Ben-Yehuda (1994), a "historical and theoretical account of moral panic" (Ungar, 2001, p. 275). The authors argue that it is possible to examine the potential existence to 'moral panic' through the existence (or absence) of five attributes: (1) concern-related to 'Others' behaviour and the possible consequences that can lead to action and mobilisation of fear-inducing practices; (2) consensus -that establishes a widespread belief that the problem is real and constitutes a threat; (3) hostility - that the persons responsible come from a group or category of people who have been subjected to inequalities and repulsion; (4) disproportionality-that applies when the issue is greater than the potential damage and, (5) volatility - when panic unexpectedly breaks out and then dissolves with stunning speed.

Table 1 provides an overview of the moral panic applied in the selected newspapers, by presenting the five attributes.

\section{Concern and consensus}

According to the UK newspapers, Daily Mail and The Independent, Dariusz Pawel Kotwica was the first criminal who benefited from the Schengen agreement of 14 June 1985, and, therefore, permeable borders have facilitated the 'uncontrolled travels' of criminals within the EU. A comment on the Daily Mail article states:
"The Schengen system is a farce and should be scrapped with immediate effect." (Comment B, Daily Mail, 28 November 2015)

The media attention on the 'need' for border management of risky populations in search of the European dream (see Bigo, 2002, 2014) claims that the volume and intensity of media discourse related to this particular criminal case (re)created a sense of 'panic' regarding the free movement of people. Didier Bigo (2002) makes this situation clear by stating that migration issues have been linked to statements centred on (in)security issues and the media are the 'heroes' in this thought-orientation. The newspapers emphasise that the criminal on the move can circulate to other countries with the same purpose in mind. Using a discourse that encourages action and order, the comments demand that borders must be closed immediately: "Close our borders now!!!!!”, "We should close our borders now." (Comment C and E, Daily Mail, 28 November 2015). Similar to other studies related to moral panic in an enlarging EU (see Nellis, 2003; Mawby and Gisby, 2009; Walsh, 2017), the members of the public argue that only the reinstatement of borders can prevent these criminals from finding new victims. According to these comments, this type of criminal can 'escape' without punishment, as explained in the following comment:

"This goes to prove that a free of checks border less Europe is a bad thing. Freedom of movement gives people such as this despicable character a massive area to commit crimes, to target vulnerable people then slip away unnoticed. (...) The borders need to be reinstated (...)." (Comment D, Daily Mail, 28 November 2015)

It is important to recall that since 2015, discussion of Brexit has led to significant challenges for ethnic minorities in the UK. The referendum fuelled a major argument that with Brexit, the UK would have "more control over the flow of immigrants (...) many people are concerned that high levels of immigration may have hurt their jobs, wages and quality of life" (Wadsworth et al., 2015, p. 2). Also, an increased number of crimes stand linked to migration issues, underlining the social apparatus of open borders in the UK (see Bigo, 2002; Clifford and White, 2017; Abbas, 2019, p. 3; El-Enany, 2018). As stated in the following comment:

"We used to have to deal just with our own murderers, rapists and terrorists. Now they come from all over the world thanks to the EU open borders policy." (Comment F, Daily Mail, 28 November 2015)

As Elspeth Guild (2001, p. 29) points out, the EU materialises itself as an 'internal border', without controls on the basis of nationalism. These norms mobilise a rhetoric based on the idea

Table 1 Moral panic model applied.

\begin{tabular}{ll} 
Attributes & Description \\
\hline Concern & Concern is focused on the emergence of 'open borders' when the Schengen agreements and the Brexit vote context applied to the \\
EU. The increase in crime news linked to migratory flows of the criminal 'Other'. \\
Production of a consensus that, in real terms, the problem exists and, therefore, moral, social and political solutions based on \\
punishment, control and surveillance of "suspicious communities" are required. \\
The "folk devils" are materialised through media narratives based on the creation of labels and stereotypes that link migration \\
to crime. \\
Thestility \\
$\begin{array}{l}\text { The 'fear of crime' that is often seen in newspapers is disproportionate to official crime statistics. Unfounded fears are (re)created } \\
\text { bolatility }\end{array}$
\end{tabular}


that borders function as walls. Nevertheless, the idea of belonging has intrinsically been linked to the concept of citizenship, which is called into question when citizens cross borders "leaving the spaces where they belong" (Bigo, 2005, p. 80). Nevertheless, the comments, in particular in the Daily Mail, fans voices that urge the UK to leave the EU in order not to maintain open borders. The Brexit debate was marked and followed by a discourse that postulates who should belong and who has the right to stay, with a sense of governance:

"Get us the hell out of the EU." (Comment X, Daily Mail, 28 November 2015)

"The referendum should hopefully see a big swing towards 'NO' and 'OUT' of the EU. Then, everyone will be checked as we won't have 'Open Borders'!!!!” (Comment E, Daily Mail, 28 November 2015)

After a string of comments, these voices also offer vivid displays of nationalism and unity, intersecting different social and geographical spaces, in which migration takes place. The data also demonstrates that borders "rather than fixed lines, (...) are now seen as processes, practices, discourses, symbols, institutions or networks through which power works" (Johnson et al., 2011, p. 62). This framework supports both a State that cultivates social control and exclusion policies for some, as well as more open borders and greater mobility for the enemy, the 'monsters' others (Zaiotti, 2007; Bosworth and Guild, 2008; Bosworth, 2014). According to the comments, the political and social regime does not offer solutions. On the contrary, it presents criminals with a 'five-star hotel'. For example:

"Kill and rape all over Europe. Come to Britain and get a five-star hotel." (Comment H, Daily Mail, 28

November 2015)

"Thanks to open borders monsters like this exist." (Comment I, Daily Mail, 28 November 2015)

People relate open borders to the increase in crime and migratory flows of immigration. One of the main concerns is the open borders made possible by the Schengen system. This framework reaffirms a "borderless world" (Bowling, 2015, p. 1) in which there is no control and regulation of those who take advantage of the borders' performance and then commit crimes across States. The outcome of Brexit highlights this context and produces a consensus "posted by (...) borders crossers" (Wonders, 2006, p. 65) which establishes a rhetoric of threat amplification. Subsequently, measures to combat the problem are shaped by a border control industry, that aims to manage populations which are considered to be suspect. This circulation develops forms of identity that are mapped by specific social practices that can provide an "ideology of circulation" (Lee and LiPuma, 2002, p. 195) as we will see below.

\section{Hostility and disproportionality}

Each country has followed its own cultural and historical development: Eastern European countries have developed for many years on the basis of a historical configuration and creation of a well-marked and incorruptible border between the East and the rest of Europe (see Bigo, 2002, 2005; Kuus, 2004; Said, 2004; Abbas, 2019). As Mignolo and Tlostanova (2006, p. 211) argue, "today, the split configuration of internal others is expressed in the continuing hierarchy of othering". Over time, Eastern Europeans have been affected by unequal, political and media intolerance. Countries such as Hungary, Slovakia, Romania, Bulgaria and Albania, are connoted as messengers of "folk devils", i.e. are linked to numerous criminal practices and illegal activities. As such, certain Eastern European countries are viewed as sending criminals to rich countries, such as the UK. This context suggests an ideology that converges on a relationship between intransigence and criminal convictions in a politics of inclusion and exclusion. This can be seen in the following comments:

"We have now more criminals entering UK from Slovakia, Hungary, Romania, Bulgaria, what next???Albania???? (Capital of crime!!!!) And no one checks at borders!!!! Stupid." (Comment J, Daily Mail, 28 November 2015)

"Seems that many don't watch the amount of Eastern Europeans from Romania and such like that find the UK an easy touch for their crime activities such as pickpockets, shoplifters, burglary, metal theft, farm animal theft among many other illegal activities, and if caught they are let out on bail only to disappear back to Eastern Europe for a while before returning for more of the same. The insanity of the $\mathrm{EU}$ is turning the UK into a cesspit." (Comment $\mathrm{N}$, The Independent, 29 November 2015)

These public discourses instigate the idea that the solution is to control borders, under the same symbolic idea of fighting an "enemy". In other words, the uncertainty of the unknown is materialised by shared representations about who must enter or leave, in the name of a European identity nationalism (Bigo, 2005, p. 36). The social impact of this distorted, poorly informed and deeply contaminated media coverage, based on a political game of obscure and harmful interests, often leads to specific individuals and groups to being marginalised and labelled through police interventions and punitive repressions. It is not just a question of punishing or rehabilitating, but of identifying and managing "groups and populations at risk" (Cohen, 1971; Mawby and Gisby, 2009; Clifford and White, 2017, p. 164). Several comments alluded to the need for stricter attitudes in the face of this irregular migratory context which is claimed to be linked to criminal practices. The comments point out that the most capable and convenient solution in this situation would be the death penalty, without any tolerance:

"And no European countries have the death penalty..." (...)

"It's a shame that the $E U$ doesn't have a death penalty. "(...)

"And I wonder why the EU abolish penalty for?!"

(Comments R, S and T, Daily Mail, 28 November 2015)

The case of the 'Euro-Ripper' is a mediated criminal event, endorsed by the brushstrokes of (in) security. Discourses of vulnerability are consolidated and declared to be imposing when the media reinforces the discourse that fits into a "construction of otherness" (Kuus, 2004, p. 473). The so-called "war on terror" (Balzacq et al., 2010, p. 6) is triggering the action of vigilant mechanisms under the sharing of a global threat proliferated, necessarily by unfounded and disproportionate alarmism, identified under the version that the population must be protected:

"Makes me feel sick. Be vigilant people!!!!!" (Comment W, Daily Mail, 28 November 2015)

In biopolitical terms, borders not only exercise power and discipline, they also identify circulations and flows considered to be dangerous. As Petit $(2019$, p. 4$)$ argues, security seems to be under a "backbone" that supports fear, with the ability to create scenarios of terror:

"Disgusting evil pervert, lock him up and let him rot and then throw away the key." (Comment V, Daily Mail, 28 November 2015) 
The creation of fear conveyed as hostility, in this case, is perceived through the exacerbation of feelings of disgust towards transgressors. There is claimed to be a need for greater vigilance and control of those who have defamed as social outcasts, the "usual" suspects (see Pantazis and Pemberton, 2009). They are the "folk devils" invoked by the media and political campaigns that articulates "territorial conceptions associated with the crime that, on the one hand, projects notions of 'European' and 'global' territory and, on the other hand, reproduces territorial inscriptions that consolidate criminal associations to populations of particular nationality" (Martins et al., 2016, p. 5). This construction of migrants as a problem on a European scale is not only a way of identifying the rival, but it is also a government technique that seeks to install alarm, anxiety and discomfort (Bigo, 2005; Lalonde, 2017; De Noronha, 2019). Nevertheless, the proportion of the different crimes portrayed represents the reverse of the official statistics represented (Sacco, 1995; Pfeiffer, 2005; Pollak and Kubrin, 2007; Cheliotis, 2010; Boda and Szabó, 2011). Disproportionality provided by the readers, and legitimised by the media discourses, is therefore higher than the potential damage. One underlying logic is that the warning of worse pictures, disproportionate measures, are often framed in the context of profiles of certain groups or populations where the label is applied under nationality and phenotype.

\section{Volatility}

The formation of public opinion has been invaded by compositions formed and consolidated in a social texture that is complex and requires different systems and social actors. Therefore, in the definition and (re) invention of dynamics of a 'moral panic' are configured with a dual function, i.e. to create a 24 -h news cycle that merely corresponds to brief eruptions that tend to fade over time (see Falkof, 2018). Informed by these issues, the comments suggest that the article showed the idea that more serial killers such as the 'Euro-Ripper' can cross Europe due to the open borders and, consequently accelerate their criminal practices in other countries:

"The article clearly means the first serial killer (that we know of) to commit murders across Europe rather than in one individual country. And that free movement in the EU facilitated his actions. Not too hard to grasp is it? (...)" (Comment A, The Independent, 29 November 2015)

In the media, as a general rule, a criminal act is understood in the light of stereotyped conceptions, based on "hierarchical criteria, conferring precise importance to each episode" (Mangone and Pece, 2017, p. 105). The social representation of crime as a form of moral panic, which I have clarified throughout this article, is based on two primary dimensions: the image of the crime and the symbolism that this image conveys. Meanwhile, after a string of comments were deleted, a new line of rhetoric emerged that recognises that "(...) The media thus tend...to reproduce symbolically the existing structure of power in society's institutional order" (Hall et al., 1978, p. 358). Comments began to highlight the fact that media narratives are establishing mechanisms that construct, in a certain period, the dominant buildings for structural and fixed identities:

"Europe has never had a serial killer before?" (Comment Z, Daily Mail, 28 November 2015)

Using the criterion of volatility, Goode and Ben-Yehuda (1994, p. 158) state that "the degree of fear, hostility and concern generated during a moral panic tends to be fairly limited temporally". Volatility changes according to current social emergencies and the growing multiculturalism of the border area. Likewise, specific stories would take on a dimension of hysteria and a sense of vulnerability, but the negative tone can quickly "become institutionalised" (Goode and Ben-Yehuda, 1994, p. 159). At a given moment, the media adopted a hostile stance towards groups of individuals from Eastern Europe, portrayed as being threatening, or focused on other groups of individuals, specifically ethnic minorities. This is a kind of numb cloud, that floats between "Us" and "Others".

This analysis corroborates what Cohen (2002) observed. In general terms, Cohen assumed the views that the media are responsible for the proliferation of sensationalist representations and the transmission of stereotypes that generate unrealistic and unfounded expectations in the general public (Chouliaraki, 2005). In fact, the media tend to increase unfounded anxieties and turn them into assets that should be feared by society (see Mawby and Gisby, 2009, p. 47; Falkof, 2018). According to Berkeley (2006, p. 30), "a multiplicity of media panics about new immigrants holds a public perception of perpetual crisis about immigration policies and social problems". With the increase in crime at the transnational level, the tension between 'open borders' and the limitation of mobile threats' (Walsh, 2017; Hilder and Kemshall, 2016, p. 132) (re)produces criminal associations that co-articulate the 'Other European' (Strath, 2002; Kuus, 2004; Said, 2004) and the "feared predator" (Fattah, 1982, p. 113). Many of these discussions led to the context of the Brexit referendum, which "would allow more control over the flow of immigrants to the UK from the rest of EU" (Wadsworth et al., 2015 , p. 2). A new metaphorical language has been introduced within the media lexis. I highlight three central point's arising from this language: (i) the narratives that instigate the appeal for (in) security caused by the entry of migrants; (ii) the highlight on more punishing cooperation and, finally, (iii) the flow of transnational movements linked to criminal practices.

\section{Concluding remarks}

The 'Euro-Ripper' story enacts different perceptions of risk, vulnerability and nationality under the effect of new (old) social emergencies (Goode and Ben-Yehuda, 1994, p. 33; Walsh, 2017). Through the media spotlight, this case observes, together with the advent of the internet, the reinforcement of an inevitable 'moral panic' (Cohen, 2002; Goode and Ben-Yehuda, 1994; Mawby and Gisby, 2009). Furthermore, and importantly, the media also track the emotional and moral force of the case to socially held views. The 'Euro-Ripper' case continues to be relevant today, with a unique and sensationalist focus mediated by the rhetoric of freedom and movement because of the Schengen agreement (it is important to recall that the UK sits outside the Schengen region). The media accounts of this case enacted the drama, hysteria and anxieties of irregular migration practices in the EU and focused on the fear of the 'Other' (see Krulichová, 2019) brought about by the lack of security managed by this migratory flow of people. I therefore argue, in line with other studies (Goode and Ben-Yehuda, 1994; Mawby and Gisby, 2009; Griffiths, 2017; Fox, 2018) that the logic of news formats promotes the reproduction of relationships of power and alarm and, encourages the public sphere to think about whom we should fear. Specifically, how our collective memories of crime are imagined? How can a reported crime originate and motivate political, social and cultural reactions and, therefore, (re)define what may become a social problem?

This study suggests that the proliferating news about this criminal case can be explained, as argued by Goode and BenYehuda (1994), through analysis of the potential for 'moral panic' through the existence of five crucial attributes: Concern, Consensus, Hostility, Disproportionality and, Volatility. Considering the overall approach, I argue that the presence of moral panic relies on various practises related to migrant populations. Citizens on the move have always existed, in particular, those who seek better conditions of life, employment and security. However, 
circulation of the 'Other' across the EU converges a stereotyped and dominant view of time and space that 'normalises' social control and surveillance, mainly motivated by countries in the centre of the EU. Nevertheless, the Leave campaign in the UK, within the Brexit debate, resounded with public perceptions that link immigrants and certain ethnic minorities to crime (Bigo, 2002, 2005, 2014; Said, 2004; Kuus, 2004; Krulichová, 2019). This article provides evidence that this representation, which is sometimes uninformed, has long-lasting ramifications, guides action in everyday life and, strengthens a world view from this labelled perspective. The article supports two main arguments: (1) The publicity and exposure to news media that covered an alarm and visibility about EU immigration mainly helps to reproduce and raise awareness related to migration as a vehicle that enables the 'folk-devil' to cross borders; (2) EU immigration is used as an umbrella term for the creation of categories of previously created suspicion targets and already socially accepted 'suspect communities'. Eastern European immigration that news media have highlighted confirms and reshapes understandings of their identities and communities as a criminal 'Other'.

The results also have shown that immigration poses a false threat to society and "project images of reality that are pending from the cultural structures and economies that support them" (Machado and Santos, 2008, p. 2). On the one hand, news media contribute to social control and reproduction as a means to entertain the public, as, on the other hand, they (re)produce cultural artefacts that lead to changes in values and identities (Machado and Santos, 2008, pp. 2-3). Further research should explain this analysis and compare the results and extend it to a qualitative study with people's perceptions of immigration and the effects on the spectre of the suspicion community.

\section{Data availability}

All data generated or analysed during this study are included in this published article.

Received: 29 April 2020; Accepted: 25 November 2020; Published online: 07 January 2021

\section{Note}

1 The case is part of a more extensive study whose main objective was to understand media narratives about the application of DNA technologies in transnational criminal cases. This study benefited from the support of EXCHANGE project [grant agreement no. 648608 to H.M.] that explores the societal, cultural, ethical, regulatory and political impacts of the use of forensic DNA technologies in the European Union, led by Helena Machado and hosted at the Communication and Society Research Centre, Institute for Social Sciences of University of Minho (Portugal).

\section{References}

Abbas M-S (2019) The promise of political blackness? Contesting blackness, challenging whiteness and the silencing of racism: a review article. Ethnicities. https://doi.org/10.1177/1468796819834046

Balzacq T, Tugba B, Didier B et al. (2010) Security practices. Int Stud Encycl Online. https://doi.org/10.1111/b.9781444336597.2010.x

Beckford M (2015) Europe's first serial killer who raped and murdered his way across continent to Britain: police investigate Pole who daubed bizarre phrases on woman's naked body in sickening crime spree across six countries. Daily Mail. https://www.dailymail.co.uk/news/article-3337785/Didserial-killer-raped-murdered-way-Europe-claim-victims-UK-Policeinvestigate-Pole-daubed-bizarre-phrases-woman-s-naked-body-sickeningcrime-spree-six-countries.html. Accessed 22 Jan 2018

Benson M (2019) Brexit and the classed politics of bordering: the British in France and European belongings. Sociology. https://doi.org/10.1177/0038038519885300

Berkeley R, Khan O, Ambikaipaker M (2006) What's New about Immigrants in Twenty-First Century Britain? Joseph Rowntree Foundation, New York

Bigo $\mathrm{D}(2002)$ Security and immigration: toward a critique of the governmentality of unease Alternatives 27(1_suppl):63-92. https://doi.org/ $10.1177 / 03043754020270$ S105
Bigo D (2005) Frontier controls in the European Union: who is in control? In: Bigo D, Guild E (ed) Controlling frontiers: free movement into and within Europe. Ashgate Publishing, Burlington, pp. 49-99

Bigo D (2014) The (in)securitization practices of the three universes of EU border control: military/navy-border guards/police-database analysts. Secur Dialogue 45(3):209-225. https://doi.org/10.1177/0967010614530459

Boda Z, Szabó G (2011) The media and attitudes towards crime and the justice system: a qualitative approach. Eur J Criminol 8(4):329-342. https://doi.org/ $10.1177 / 1477370811411455$

Bosworth M (2014) Inside immigration detention. Oxford University Press, Oxford Bosworth M, Guild M (2008) Governing through migration control: security and citizenship in Britain. Br J Criminol 48(6):703-719. https://doi.org/10.1093/ bjc/azn059

Bowling B (2015) The borders of punishment: towards a criminology of mobility. I. In: Aas KF, Bosworth M (ed) Migration and punishment: citizenship, crime control, and social exclusion. Oxford University Press, Oxford, pp. 1-15

Boyd SM (2016) From news to comment: tracing text trajectories in news reporting about the Amanda Knox Trial. In: Gies L, Bortoluzzi M (ed) Transmedia Crime Stories: the trial of Amanda Knox and Raffaele Sollecito in the globalised media sphere. Palgrave Macmillan, London, pp. 139-164

Cheliotis LK (2010) The ambivalent consequences of visibility: crime and prisons in the mass media. Crime Media Culture 6(2):169-184. https://doi.org/ $10.1177 / 1741659010378629$

Chouliaraki L (2005) Media discourse and the public sphere. In: Howarth D, Torfing J (ed) Discourse theory in European politics. Palgrave Macmillan, London, pp. 45-71

Clegg R (2019) UK and non-UK people in the labour market: February 2019. Office for National Statistics. https:/www.ons.gov.uk/employmentandlabourmarket/ peopleinwork/employmentandemployeetypes/articles/ukandnonukpeopleinthel abourmarket/february2019. Accessed 22 Jan 2020

Clifford K, White R (2017) Media and crime: content, context and consequence. Oxford University Press, Oxford

Coe K, Kenski K, Rains SA (2014) Online and uncivil? Patterns and determinants of incivility in newspaper website comments. J Commun 64(4):658-679. https://doi.org/10.1111/jcom.12104

Cohen S (1971) Images of deviance, vol 1293. Penguin Books Ltd, London

Cohen S (2002) Folk devils and moral panics. The creation of the mods and the rockers. Blackwell, London

Curtice J (2017) Brexit: the vote to leave the EU. Litmus test or lightning rod? No. 34; British social attitudes. NatCen Social Research

Dahlgren P (2009) Media and political engagement: citizens, communication, and democracy. Cambridge University Press, Cambridge

De Noronha L (2019) Deportation, racism and multi-status Britain: immigration control and the production of race in the present. Ethn Racial Stud 42 (14):2413-2430. https://doi.org/10.1080/01419870.2019.1585559

Dorling D (2016) Brexit: the decision of a divided country. BMJ 354:1-3. https:// doi.org/10.1136/bmj.i3697

Dumitrescu L (2018) The securitization of East-European migrants. The ocurrence of liminal identities in the European Union. In: Balica E, Marinescu V (ed) Migration and crime: realities and media representations. Palgrave Macmillan, London, pp. 69-86

El-Enany N (2018) The next British empire. IPPR Prog Rev 25(1):30-38. https:// doi.org/10.1111/newe.12089

Eberl J-M, Meltzer CE, Heidenreich T, Herrero B, Theorin N, Berganza R, Boombaarden HG, Schemer C, Strömbäck J (2018) The European media discourse on immigration and its effects: a literature review. Ann Int Commun Assoc 42(3):207-223. https://doi.org/10.1080/23808985.2018.1497452

Falkof N (2018) On moral panic: some sirections for further development. Crit Sociol 5(4):1-18. https://doi.org/10.1177/0896920518803698

Fattah EA (1982) Public opposition to prison alternatives and community corrections: a strategy for action. Can J Crim Crim Justice 24(4):371-385

Fox B (2018) Making the headlines: EU immigration to the UK and the wave of new racism after Brexit. In: Balica E, Marinescu V (ed) Migration and crime: realities and media representations. Palgrave Macmillan, London, pp. 87-107

Goode E, Ben-Yehuda N (1994) Moral panics: culture, politics, and social construction. Annu Rev Sociol 20:149-171. https://doi.org/10.1146/annurev. so.20.080194.001053

Goodwin M, Milazzo C (2017) Taking back control? Investigating the role of immigration in the 2016 vote for Brexit. Br J Politics Int Relat 19(3):450-464. https://doi.org/10.1177/1369148117710799

Griffiths M (2017) Foreign, criminal: a doubly damned modern British folk-devil. Citizensh Stud 21(5):527-546. https://doi.org/10.1080/13621025.2017.1328486

Guild E (2001) Moving the borders of Europe. Inaugural Lecture Universiteit Nijmegen, Faculteit der Rechtsgeleerdheid. http://cmr.jur.ru.nl/cmr/docs/ oratie.eg.pdf. Accessed 23 Feb 2018

Gurminder KB (2017) Locating Brexit in the pragmatics of race, citizenship and empire. In: Outhwaite W (ed) Brexit: sociological tesponses. Anthem Press, London, pp. 1-8 
Hall S, Critcher C, Jefferson T et al. (1978) Policing the crisis: mugging, the state and law and order. Macmillan Press, London

Henrich N, Holmes B (2013) Web news readers' comments: towards developing a methodology for using on-line comments in social inquiry. J Media Commun Stud 5(1):1. https://doi.org/10.5897/JMCS11.103

Hilder S, Kemshall H (2016) Serious violent or sexual offenders travelling across European Union borders: ideological and ethical challenges of information exchange. Eur J Probat 8(3):128-145. https://doi.org/10.1177/2066220316678749

Hutchings PB, Sullivan KE (2019) Prejudice and the Brexit vote: a tangled web. Palgrave Commun 5(1):1-5. https://doi.org/10.1057/s41599-018-0214-5

International Organization for Migration (2020) World migration report. https:// publications.iom.int/books/world-migration-report-2020. Accessed 20 Jan 2020

Johnson C, Jones R, Paasi A et al. (2011) Interventions on rethinking 'the border' in border studies. Political Geogr 30(2):61-69. https://doi.org/ 10.1016/j.polgeo.2011.01.002

Khan S (2015) Dariusz Pawel Kotwica: 'Europe's first serial killer' could have committed 'serious crimes' in Britain. The Independent. Available via https:// www.independent.co.uk/news/world/europe/dariusz-pawel-kotwica-europefirst-serial-killer-serious-crimes-britain-poland-polish-sweden-austriaa6753326.html. Accessed 22 Jan 2018

Krulichová E (2019) The relationship between fear of crime and risk perception across Europe. Criminol Criminal Justice 19(2):197-214. https://doi.org/ $10.1177 / 1748895818757832$

Kuus M (2004) Europe's Eastern expansion and the reinscription of otherness in East-Central Europe. Prog Hum Geogr 28(4):472-489. https://doi.org/ $10.1191 / 0309132504 \mathrm{ph} 498 \mathrm{oa}$

Lalonde PC (2017) Cyborg work: borders as simulation. Br J Criminol 58 (6):1361-1380. https://doi.org/10.1093/bjc/azx070

Lee B, LiPuma E (2002) Cultures of circulation: the imaginations of modernity. Public Cult 14(1):191-213. https://doi.org/10.1215/08992363-14-1-191

Machado H, Granja R (2018) Ethics in transnational forensic DNA data exchange in the EU: constructing boundaries and managing controversies. Sci Cult 27:242-64. https://doi.org/10.1080/09505431.2018.1425385

Machado H, Santos F (2008) Justiça tecnológica: promessas e desafios. Edições Ecopy, Porto

Mangone E, Pece E (2017) Europe/Mediterranean: media treatment of the immigrant. J Mediterr Knowl 2(1):101-111

Martins M, Granja R, Machado H (2016) Risco, Segurança e Criminalidade: O Suspeito Transnacional. In: Atas do Congresso IX Português de SociologiaPortugal, Território de territórios. http://hdl.handle.net/10316/43715

Mawby RC, Gisby W (2009) Crime, media and moral panic in an expanding European Union. Howard J Criminal Justice 48(1):37-51. https://doi.org/ 10.1111/j.1468-2311.2008.00547.x

Mignolo WD, Tlostanova MV (2006) Theorizing from the borders: shifting to geoand body-politics of knowledge. Eur J Soc Theory 9(2):205-221. https://doi. org/10.1177/1368431006063333

Mihelj S, Koenig T, Downey J, Štetka V (2008) Mapping European ideoscapes: examining newspaper debates on the EU Constitution in seven European countries. Eur Soc 10(2):275-301

Nellis M (2003) News media, popular culture and the electronic monitoring of offenders in England and Wales. Howard J Criminal Justice 42(1):1-31. https://doi.org/10.1111/1468-2311.00263

Ofcom. News consumption in UK: 2019. https://www.ofcom.org.uk/_data/assets/ pdf_file/0027/157914/uk-news-consumption-2019-report.pdf. Accessed 17 Jul 2020

Pantazis C, Pemberton S (2009) From the "old" to the "new" suspect community: examining the impacts of recent UK counter-terrorist legislation. $\mathrm{Br} \mathrm{J}$ Criminol 49:646-66. https://doi.org/10.1093/bjc/azp031

Petit P (2019) 'Everywhere Surveillance': global surveillance regimes as techno-securitization. Sci Cult 29(1):30-56. https://doi.org/10.1080/ 09505431.2019 .1586866

Pfeiffer C (2005) Media use and its impacts on crime perception, sentencing attitudes and crime policy. Eur J Criminol 2(3):259-285. https://doi.org/ $10.1177 / 1477370805054099$

Pollak JM, Kubrin CE (2007) Crime in the news: how crimes, offenders and victims are portrayed in the media. J Criminal Justice Popul Cult 14(1):59-83

Sacco VF (1995) Media constructions of crime. Ann Am Acad Political Soc Sci 539 (1):141-154. https://doi.org/10.1177/0002716295539001011

Said EW (2004) Orientalism. Vintage Books Edition, New York

Da Silva MT (2013) Online forums, audience participation and modes of political discussion: readers' comments on the Brazilian presidential election as a case study. Commun Soc 26(4):175-193
Da Silva MT (2015) What do users have to say about online news comments? Readers' accounts and expectations of public debate and online moderation: a case study. Participations 12(2):32-44

Skovsgaard M (2014) A tabloid mind? Professional values and organizational pressures as explanations of tabloid journalism. Media Cult Soc 36 (2):200-218. https://doi.org/10.1177/0163443713515740

Strath B (2002) A European identity: to the historical limits of a concept. Eur J Soc Theory 5(4):387-401. https://doi.org/10.1177/136843102760513965

Strauss A, Corbin J (1994) Grounded theory methodology: an overview. In: Denzin NK, Lincoln YS (ed) Handbook of qualitative research. Sage Publications, Inc, Thousand Oaks, pp. 273-285

Tong J, Zuo L (2019) Othering the European Union through constructing moral panics over ' $\mathrm{im} /$ migrant (s)'in the coverage of migration in three British newspapers, 2011-2016. Int Commun Gaz 81(5):445-469

Ungar S (2001) Moral panic versus the risk society: the implications of the changing sites of social anxiety. Br J Sociol 52(2):271-291. https://doi.org/ $10.1080 / 00071310120044980$

Wadsworth J (2015) Immigration and UK Labour Market (CEP 2015 election analyses series). LSE Centre for Economic Performance, Paper EA019

Wadsworth J, Dhingra S, Ottaviano G et al. (2015) Brexit and the impact of immigration on the UK (Brexit analysis No. 5). LSE Centre for Economic Performance, London

Walsh J (2017) Moral panics by design: the case of terrorism. Curr Sociol 65 (5):643-662. https://doi.org/10.1177/0011392116633257

Walter S (2019) Better off without you? How the British media portrayed EU citizens in Brexit news. Int J Press/Politics 24(2):210-232. https://doi.org/ $10.1177 / 1940161218821509$

Wonders NA (2006) Global flows, semi-permeable borders and new channels of inequality. In: Pickering S, Weber SL (ed) Borders, mobility and technologies of control. Springer, Dordrecht, pp. 63-86

Zaiotti R (2007) Revisiting Schengen: Europe and the emergence of a new culture of border control. Perspect Eur Politics Soc 8(1):31-54. https://doi.org/ $10.1080 / 15705850701204087$

\section{Acknowledgements}

This work was supported by the European Research Council under the European Union's Horizon 2020 research and innovation programme [grant agreement no. 648608 to H.M.], within the project 'EXCHANGE-Forensic geneticists and the transnational exchange of DNA data in the EU: Engaging science with social control, citizenship and democracy' led by Helena Machado and hosted at the Communication and Society Research Centre, Institute for Social Sciences of University of Minho (Portugal).

\section{Competing interests}

The author declares no competing interests.

\section{Additional information}

Correspondence and requests for materials should be addressed to M.M.

Reprints and permission information is available at http://www.nature.com/reprints

Publisher's note Springer Nature remains neutral with regard to jurisdictional claims in published maps and institutional affiliations.

Open Access This article is licensed under a Creative Commons Attribution 4.0 International License, which permits use, sharing, adaptation, distribution and reproduction in any medium or format, as long as you give appropriate credit to the original author(s) and the source, provide a link to the Creative Commons license, and indicate if changes were made. The images or other third party material in this article are included in the article's Creative Commons license, unless indicated otherwise in a credit line to the material. If material is not included in the article's Creative Commons license and your intended use is not permitted by statutory regulation or exceeds the permitted use, you will need to obtain permission directly from the copyright holder. To view a copy of this license, visit http://creativecommons.org/ licenses/by/4.0/.

(C) The Author(s) 2021 